\title{
A Quantitative Study on Muslim Milk Mother's Understanding Towards the Islamic Concept of Wet Nursing
}

\section{Salasiah Hanin Hamjah}

Universiti Kebangsaan Malaysia https://orcid.org/0000-0002-0877-6570

Norsyamlina Che Abdul Rahim ( $\nabla$ syamlina_rahim@yahoo.com )

Institute for Public Health, National Institutes of Health, Ministry of Health Malaysia https://orcid.org/0000-0003-4045-6566

\section{Nurhidayah Muhammad Hashim}

Universiti Teknologi MARA

\section{Nora'inan Bahari}

Kolej Universiti Islam Antarabangsa Selangor

\section{Zuliza Mohd. Kusrin}

Universiti Kebangsaan Malaysia

\section{Latifah Abdul Majid}

Universiti Kebangsaan Malaysia

\section{Rafeah Saidon}

MARA University of Technology: Universiti Teknologi MARA

Muhamad Zariff llias

MARA Institute of Technology: Universiti Teknologi MARA

\section{Research}

Keywords: breastfeeding, wet nursing, understanding, motivating factors, milk mothers, Islamic laws

Posted Date: February 19th, 2021

DOl: https://doi.org/10.21203/rs.3.rs-221588/v1

License: (c) (i) This work is licensed under a Creative Commons Attribution 4.0 International License. Read Full License 


\section{Abstract}

Background: The practice of wet nursing or breastfeeding of another woman's child in Malaysia is on the rise due to the emergence of public awareness about the importance and benefits of breast milk. However, it is concerning that lack of understanding of the Islamic law on wet nursing among the milk mothers, especially those relating to mahram (unmarriageability), nasab (lineage) and inheritance is a problem in the society. Hence, this study aims to determine milk mothers' knowledge about the legal implications of wet nursing and understand the factors influencing the practice.

Methods: This was a cross-sectional descriptive study that was carried out from January to July 2019. This study was conducted on 100 women who had breastfed another child in Selangor. Data were obtained using a validated questionnaire (Cronbach alpha=0.8) and processed using the SPSS software.

Results: Results showed that the majority of respondents understand the law on wet nursing especially on marriage, conditions and method of feeding. Nevertheless, the respondents still need to understand further the laws relating to nasab (lineage), guardianship and inheritance involving the milk child. This study also showed various factors that have influenced the wet-nursing practice in society.

Conclusions: This study has several significant implications includes creating awareness to enhance knowledge relating to wet-nursing practice. Researches related to wet nursing and matters connected to it should continue so as to bring about much good to society.

\section{Background}

Mother's breast milk is scientifically proven to contain essential nutrients beneficial for the physical and mental development of infants for their growth (Rehman et al., 2017; Berlanga-Macias et al., 2020). Mother's breast milk is also found to help strengthen the infant's antibodies or immunity against dangerous diseases (Dennis, 2002; Gertosio et al., 2016; Harris et al., 2019). Due to awareness of the importance of mother's milk for an infant's healthy growth and intelligence, mothers are determined to breastfeed their infants even though they are working mothers. The technological invention of the sophisticated milking machine helps the process of feeding breast milk as expressed milk can be frozen and given to the infant later while the mother is working (Shinde, 2015; Hapsah et al., 2002; Syh. Noorul Madihah et al., 2018; Tanriverdi et al., 2019). In addition, the development of social networks such as whatsapp, twitter, and facebook have allowed online support group for mothers to be formed. Other than moral support from husband and family, online support groups also help to motivate mothers in feeding infants with breast milk exclusively for at least six months (Hapsah et al., 2002; Sandra \& Ahmad Syafiq, 2010; Siti Mariam, 2013; Hagos \& Tadesse, 2020; Baeza et al. 2016).

Increasing public knowledge about breast milk's nutrients for infants causes mothers who are unable to breastfeed their infants by themselves to hire milk mothers or even buy breast milk from other women. This practice has given rise to the phenomenon of wet nursing. This phenomenon seems to be 
problems. However, women who become milk mothers need to understand the effects in Shariah law, especially if they have established milk kinship with the infants. The problem among the milk mothers is that they might not know the legal effects in terms of Shariah law. If this ignorance is not overcome, it is feared that there might be future marriages between milk siblings, which contradicts the objectives of Shariah (Maqasid al-Syari'iyyah), namely, to preserve a person's lineage (Hifz al-Nasl).

The law on wet nursing is about mahram (unmarriageability). Along with some conditions, a child fed on another woman's milk becomes her milk child permanently. The milk child is strictly forbidden to marry the milk mother or milk father and their offspring or descendants due to their blood ties. Their children are also mahram (unmarriageable), and their milk kinship does not nullify ablution as they are allowed to mix as milk siblings, subject to aurat limits (or hijab rules), just as the milk child would with his/her own biological siblings. The lineage of the milk mother whom the milk child is forbidden to marry are her siblings, her sons and daughters, his/her female grandchildren and the mother of the milk mother. Likewise, the lineage of the milk father to whom the milk child is mahram (unmarriageable) include the milk father's siblings, his/her daughters even from another wife, his/her female grandchildren and his/her mother. This is the consensus of the four Sunni schools of law, Syafi'i, Hanafi, Maliki and Hanbali (Sharbini, 1978; al-Sarkhasi, n.d.; al-Dusuqi, n.d.). In addition, the law describes the conditions for wet nursing which need to be understood to legally establish an infant's status as a milk child. The conditions that are required to establish milk kinship are related to woman's breast milk, amount of feeding, age of infant while feeding and mode of feeding (Mohammad Nidzam \& Mohd Daud, 2018). All stated above included that she is a woman who has reached puberty.

According to Hanafi and Maliki school of law, the number of feeding or the amount of milk fed to an infant does not affect the status of milk kinship. On the other hand, according to Shafi'i and Hanbali school of law, infants need to be satiated five or more times to establish milk kinship between the woman and the infant (al-Syirazi, 1983, Ibn Qudamah,1983). In terms of age of infant, the majority of jurists agree that the milk child shall not be more than two years old for the law on mahram (unmarriageability) based on milk kinship to apply to both parties. (Al-Mawardi, 1996; Al-Kasani, 2000; Ibn Qudamah, 1983). In addition, the mode of feeding also needs to be examined in order to determine the legal status of milk kinship. Scholars agree by consensus that an infant becomes a milk child if the infant is fed breast milk for five or more times by the milk mother, whether directly from the breast or from a bottle, spoon, tube or syringe. The Muslim society too needs to know the law on feeding breast milk to someone else's child in matters of guardianship, lineage and inheritance. In terms of lineage (nasab), a milk child does not take the milk father's lineage. Likewise, the milk father is not its legal guardian (Zilal, 2014). In terms of inheritance, the milk child does not inherit from the milk mother, nor she from him (Zanariah et al., 2018). This discussion clearly shows that the legal status of milk kinship is an important matter which needs to be thoroughly understood by all parties involved, including the milk mother, the milk child and their respective families.

Generally, countless research studies on milk children have been done previously by many researchers, 3), Hapsah et al. (2002), Anna (2001), Ayu Aima (2002), 
Ahluwalia (2005), Dennis (2002), Normadiah \& Zuliza (2014), Normadiah et al. (2012), Radzniwan et al. (2009), Tengku Alina et al. (2012), Normadiah et al. (2015) and many others. Previous research mostly studied mothers' understanding on the concept of wet nursing, their knowledge on breastfeeding exclusively, the attitude of milk mothers and their practice, the duration of their practice, the rights and duties in feeding, the challenges underwent by career mothers and the factors for the discontinuation of breast feeding by some mothers.

Some previous research studies also focused on the benefits of breast milk to an infant's growth and health, such as by Norita et al. (2019), Normadiah \& Siti Fatimah (2009), Ward et al. (2013), Rehman et al. (2017), Berlanga-Macias et al. (2020), Del Ciampo \& Del Ciampo (2018), Spiro (2017), Gertosio et al. (2016), Harris et al. (2019) and many more who empirically proved that mother's milk is the best for infants. In addition, research on breastfeeding someone else's infant were also conducted by Flores-Antón et al. (2017); Lommen \& Brown (2015); Zilal (2015), Azizah (2011) and Zilal \& Farahwahida (2015) but these research are more toward breastfeeding others' infants as adopted or foster children. Research on breastfeeding adopted or foster children was also conducted in the West by Gribble (2006), who explained that breastfeeding is beneficial to mothers and children in terms of bonding and calming effect.

Meanwhile, there were also some research studies that focused on the laws on wet nursing, including the research done by Zanariah et al. (2018) on the Muslim society's awareness of the laws relating to wet nursing. They selected Muslim respondents from both genders to participate in their study. Contrarily, this research paper focused only on milk mothers who are still practicing it during the study. In short, past research did not study wet nursing, especially, milk mothers' understanding of the legal implications of feeding someone else's infant and the factors which encourage their willingness to feed them. Hence, this research is for the purpose of analysing Muslim milk mothers' understanding of the law on feeding breast milk to someone else's infant and identifying the motivating factors for their willingness to do so.

\section{Methods}

\section{Study design and setting}

This study used a quantitative research design based on a purposive sampling method carried out on 100 milk mothers aged 21 to 50 years old. Individuals who have consented to participate and had rich information were the targets hoping that they could provide more extensive data. The locations of this study involved all nine districts (Sabak Bernam, Hulu Selangor, Kuala Selangor, Kuala Langat, Sepang, Hulu Langat, Gombak, Petaling and Klang) in Selangor, Malaysia. This study was carried out from January 2019 to July 2019.

\section{Sample and recruitment}


Data was collected using self-administered questionnaire via Google form. Researchers developed a questionnaire survey to determine the practice and processes implemented by Muslim mothers. The questionnaire consisted of two parts: sociodemographic characteristics, and women's practice on wet nursing. The inclusion criteria of respondents were i) Mothers who breastfeed other children (atlest one child); ii) Mother resident in Selangor; iii) Mother aged below 50 years old; iv) Consented to participate. The exclusion criteria were: i) Non-Muslim respondents; ii) Muslims outside of Selangor or living in other Malaysian states.

\section{Pilot test}

A pilot study on 29 wet nursing muslim mothers was conducted. This pilot study is essential for assessing the validity of the instrument and evaluating the level of difficulty of the questions posted. This pilot study is also designed to examine the reliability test (internal consistency) using Cronbach's alpha. Cronbach's a was used to assess the homogeneity of the questions for internal consistency within the test. The overall value of Cronbach Alpha assessment instruments for the pilot study exceeded the reference value $(a=0.8)[20]$.

\section{Data collection}

The study was ethically approved by the Medical Research and Ethics Committee, Ministry of Health Malaysia with code NMRR-20-2503-57029 (IIR). An informed consent was acquired before each respondent administered the questionnaire online. This questionnaire was available in Malay language because most of the respondents were Malays, and they understood and preferred the language.

\section{Data analysis}

The results for each questionnaire were compiled in Survey Monkey, an online survey program, and the total responses to each question were compiled for analysis. The data from this questionnaire was analysed using the Statistical Package for Social Sciences (SPSS) version 22. Categorical variables were summarized as numbers and percentages, whereas normally distributed continuous variables were presented as means and standard deviations. $p$-value less than 0.05 was considered statistical significant.

\section{Results}

\section{Respondents' Characteristics}

Table 1 shows that all respondents were wet nurses who lived in Selangor. Variables of the study were age, marital status, several children are breastfed, residence, education level, occupation, and total income. The respondents in this studv were 21 to 50 years old. The results showed that all respondents Loading [MathJax]/jax/output/CommonHTML/jax.js 
were married (100.0\%). In terms of education, the respondents were examined from various educational backgrounds: Sijil Pelajaran Malaysia (SPM), Certificate, Diploma, Bachelor's Degree, Master's Degree, and the highest level of Doctor of Philosophy. The study showed that respondents with a bachelor's degree outperformed respondents from other education levels of $48.0 \%$. In terms of employment, $37.0 \%$ of the respondents were civil servants. While $32.0 \%$ of respondents worked in the private sector, and only $3.0 \%$ of respondents were students. Therefore, most of the respondents in this study consist of professionals who have monthly income that ranged from RM3001 to RM6000 (40.0\%). Whereas 31.0\% of respondents had RM1001 to RM3000 salary, and only $17.0 \%$ of respondents had below RM1000 salary. 
Table 1

Socio-demography of respondents

\begin{tabular}{|c|c|c|}
\hline \multirow[t]{3}{*}{ Item } & \multicolumn{2}{|l|}{ Respondent } \\
\hline & Frequency & Percentage \\
\hline & (n) & (\%) \\
\hline \multicolumn{3}{|l|}{ Age (year) } \\
\hline $21-30$ & 30 & 30.0 \\
\hline $31-40$ & 64 & 64.0 \\
\hline $41-50$ & 6 & 6.0 \\
\hline \multicolumn{3}{|l|}{ Marriage status } \\
\hline Single & 0 & 0 \\
\hline Married & 100 & 100.0 \\
\hline Divorce & 0 & 0 \\
\hline \multicolumn{3}{|c|}{ Residence (district) } \\
\hline Kuala Selangor & 3 & 3.0 \\
\hline Kuala Langat & 5 & 5.0 \\
\hline Sepang & 8 & 8.0 \\
\hline Hulu Langat & 26 & 26.0 \\
\hline Gombak & 12 & 12.0 \\
\hline Petaling & 28 & 28.0 \\
\hline Klang & 18 & 18.0 \\
\hline Sabak Bernam & 0 & 0 \\
\hline Hulu Selangor & 0 & 0 \\
\hline \multicolumn{3}{|l|}{ Education level } \\
\hline SPM & 7 & 7.0 \\
\hline Certificate & 2 & 2.0 \\
\hline Diploma & 20 & 20.0 \\
\hline Bachelor & 48 & 48.0 \\
\hline Master & 19 & 19.0 \\
\hline nmonHTML/jax.js & 4 & 4.0 \\
\hline
\end{tabular}




\begin{tabular}{|lll|}
\hline Item & \multicolumn{2}{l|}{ Respondent } \\
\hline Occupation & & \\
\hline Civil sector & 37 & 37.0 \\
\hline Private sector & 32 & 32.0 \\
\hline Self-employed & 13 & 13.0 \\
Housewife & 15 & 15.0 \\
Student & 3 & 3.0 \\
Income & & \\
Below RM1000 & 17 & 17.0 \\
RM1000-RM3000 & 31 & 31.0 \\
RM3001-RM6000 & 40 & 40.0 \\
RM6001-RM9000 & 10 & 10.0 \\
RM9001-above & 2 & 2.0 \\
\hline
\end{tabular}

\section{Knowledge of wet nursing in Islamic law}

Research findings discussed milk mothers' understanding of the law on feeding breast milk to someone else's infant or wet nursing (Table 2) and the factors for their willingness to do so (Table 3). This research finds that the item with the highest mean value is 'A milk child is forbidden to marry his milk mother or milk father' (mean $=3.67$ ), followed by item 'A milk daughter/son is forbidden to marry the biological sons and daughters of his milk mother' (mean $=3.65$ ), item 'Someone else's infant aged not more than two years old and fed with the breast milk of a woman can be her milk infant' (mean $=3.57$ ), item 'Islam permits feeding an infant with expressed milk' (mean $=3.55$ ), and item 'A mother may feed her milk to someone else's infant subject to her husband's permission' (mean $=3.52$ ).

This research finds that the item 'The aurat limits (or hijab) for a milk child in relation to his milk parents are the same as for his/her biological parents' scored a moderate high mean (mean = 3.43), item 'The legal condition which establishes the status of milk mother is five different feedings times until satiety' (mean $=3.40$ ), item 'Ablution is nullified if a milk child touches his milk mother/father (mean = 3.30) and item 'A milk child takes the lineage of his biological parents' (mean =3.16). Research results find that the item with the lowest mean value is item 'A milk father can be the guardian of his milk daughter's marriage' (mean $=1.95$ ) and item 'A milk child can inherit property from his milk parents' (mean $=1.83$ ) and 'Islam permits milk mothers to feed someone else's infant only through breastfeeding' (mean $=1.54$ ). 
Table 1

Knowledge of wet nursing in Islamic law

\begin{tabular}{|c|c|c|c|c|c|c|}
\hline No & Item & $\begin{array}{l}\text { Strongly } \\
\text { Disagree }\end{array}$ & $\begin{array}{l}\text { Dis- } \\
\text { agree }\end{array}$ & Agree & $\begin{array}{l}\text { Strongly } \\
\text { Agree }\end{array}$ & $\begin{array}{l}\text { Mean } \\
\pm \text { SD }\end{array}$ \\
\hline 1 & $\begin{array}{l}\text { It is forbidden for a milk child to marry his } \\
\text { milk mother/father. }\end{array}$ & 1 & 0 & 30 & 69 & $\begin{array}{l}3.67 \\
\pm 0.53\end{array}$ \\
\hline 2 & $\begin{array}{l}\text { A milk daughter/son is forbidden to marry } \\
\text { the biological child of her/his milk mother. }\end{array}$ & 1 & 0 & 32 & 67 & $\begin{array}{l}3.65 \\
\pm 0.54\end{array}$ \\
\hline 3 & $\begin{array}{l}\text { Someone else's infant aged not more than } \\
\text { two years old and fed with the breast milk } \\
\text { of a woman can be her milk child. }\end{array}$ & 0 & 4 & 35 & 61 & $\begin{array}{l}3.57 \\
\pm 0.57\end{array}$ \\
\hline 4 & $\begin{array}{l}\text { Islam permits feeding infant with expressed } \\
\text { milk of the milk mother. }\end{array}$ & 0 & 4 & 37 & 59 & $\begin{array}{l}3.55 \\
\pm 0.58\end{array}$ \\
\hline 5 & $\begin{array}{l}\text { A mother may feed her milk to someone } \\
\text { else's infant subject to her husband's } \\
\text { permission. }\end{array}$ & 1 & 1 & 43 & 55 & $\begin{array}{l}3.52 \\
\pm 0.58\end{array}$ \\
\hline 6 & $\begin{array}{l}\text { The aurat limits (or hijab) for a milk child in } \\
\text { relation to his milk parents are the same as } \\
\text { toward his biological parents. }\end{array}$ & 0 & 4 & 49 & 47 & $\begin{array}{l}3.43 \\
\pm 0.57\end{array}$ \\
\hline 7 & $\begin{array}{l}\text { The legal condition which establishes the } \\
\text { status of milk mother is } 5 \text { different feeding } \\
\text { times until satiety. }\end{array}$ & 2 & 10 & 34 & 54 & $\begin{array}{l}3.40 \\
\pm 0.75\end{array}$ \\
\hline 8 & $\begin{array}{l}\text { Ablution is nullified if a milk child touches } \\
\text { his milk parents. }\end{array}$ & 4 & 9 & 40 & 47 & $\begin{array}{l}3.30 \\
\pm 0.80\end{array}$ \\
\hline 9 & $\begin{array}{l}\text { A milk child takes the lineage of his/her } \\
\text { biological parents. }\end{array}$ & 3 & 14 & 47 & 36 & $\begin{array}{l}3.16 \\
\pm 0.78\end{array}$ \\
\hline 10 & $\begin{array}{l}\text { A milk father can be the guardian for a milk } \\
\text { daughter's marriage. }\end{array}$ & 41 & 31 & 20 & 8 & $\begin{array}{l}1.95 \\
\pm 0.97\end{array}$ \\
\hline 11 & $\begin{array}{l}\text { A milk child may inherit the property of his } \\
\text { milk parents. }\end{array}$ & 38 & 43 & 17 & 2 & $\begin{array}{l}1.83 \\
\pm 0.78\end{array}$ \\
\hline 12 & $\begin{array}{l}\text { Islam allows a milk mother to feed } \\
\text { someone else's infant only through } \\
\text { breastfeeding. }\end{array}$ & 50 & 47 & 2 & 1 & $\begin{array}{l}1.54 \\
\pm 0.59\end{array}$ \\
\hline
\end{tabular}

\section{Motivating factor influencing the wet nursing practice}

The item that scored the highest mean for the factors influence milk mother to breastfeed is "I feed my milk to someone else's infant to help mothers who do not have enough breast milk" (mean =3.36). This is followed by item "I feed someone else's infant because I have surplus breast milk" (mean = 3.18) and item "I feed someone else's infant because its mother has a health problem which prevents 
breastfeeding" (mean = 3.01). The item which obtained the least agreement is "I feed someone else's infant as a source of income" (mean $=1.41)$.

Table 2

Motivating factors influence milk mother to breastfeed

\begin{tabular}{|c|c|c|c|c|c|c|}
\hline No. & Item & $\begin{array}{l}\text { Strongly } \\
\text { Disagree }\end{array}$ & Disagree & Agree & $\begin{array}{l}\text { Strongly } \\
\text { Agree }\end{array}$ & $\begin{array}{l}\text { Mean } \\
\pm \text { SD }\end{array}$ \\
\hline 1 & $\begin{array}{l}\text { I feed my breast milk to someone else's } \\
\text { infant because I have surplus milk }\end{array}$ & 4 & 12 & 46 & 38 & $\begin{array}{l}3.18 \\
\pm 0.80\end{array}$ \\
\hline 2 & $\begin{array}{l}\text { I feed my breast milk to some else's } \\
\text { infant as a source of income. }\end{array}$ & 60 & 39 & 1 & 0 & $\begin{array}{l}1.41 \\
\pm 0.51\end{array}$ \\
\hline 3 & $\begin{array}{l}\text { I feed my breast milk to someone else's } \\
\text { infant to help mothers who do not have } \\
\text { enough breast milk. }\end{array}$ & 2 & 6 & 46 & 46 & $\begin{array}{l}3.36 \\
\pm 0.69\end{array}$ \\
\hline 4 & $\begin{array}{l}\text { I feed my breast milk to someone else's } \\
\text { infant because its mother has health } \\
\text { problems which prevent breastfeeding. }\end{array}$ & 5 & 22 & 40 & 33 & $\begin{array}{l}3.01 \\
\pm 0.87\end{array}$ \\
\hline
\end{tabular}

\section{Discussion}

This research found $99.0 \%$ of respondents agree that a milk child is forbidden to marry his milk mother or milk father. Only $1.0 \%$ disagrees with this item. This showed that only one person among respondents did not understand the permanent prohibition of marriage between a milk child to his milk mother or father. This research finding is in line with a finding by Zanariah et al. (2018) that $87.0 \%$ of respondents agree that a milk son is prohibited from marrying his milk mother, and $71.5 \%$ of respondents agree that a milk daughter cannot marry her milk mother's husband.

The item which scored the second highest mean value revolves around the marriage law, namely, 'A milk daughter/son is forbidden to marry the biological sons and daughters of his milk mother' (mean $=3.65$ ). About $67.0 \%$ of respondents in this research strongly agree and $32.0 \%$ agree with this item statement. Only $1.0 \%$ strongly disagrees with it. This finding also showed that only one respondent does not understand the legal permanent prohibition of marriage between the milk child and the biological offspring of the milk mother. Generally, this research found that milk mothers understand the legal effect of feeding breast milk in terms of marriage laws, namely, it is forbidden for a milk child to marry the milk mother or father as well as the milk siblings just as he/she is forbidden to marry his own biological mother or father and his biological siblings by the same parents or the same mother or the same father (Zanariah et al., 2018; al-Syafi i, n.d.; al-Mawardi, 1996; Ibn Rusyd, n.d.; Ibn Qudamah, 1983). In addition, the item which scored the third highest mean value relates to the age of the infant fed to become a milk child, is 'Someone else's child aged not more than two years old and fed with breast milk can be a milk child' (mean $=3.57$ ). $96.0 \%$ of respondents agree that only an infant aged not more than two years and fed with the breast milk of the milk mother becomes a milk child. Generally, this research found that 
respondents understand the legal age of the fed infant to establish milk kinship (al-Qurtubi, 2004; alBaidawi, n.d.; al-Mawardi, 1996; al-Jassas, 2010 and al-Nawawi, 2005).

In addition, research respondents also understood well the legal condition of 5 different feeding times until satiety in the item 'The legal condition which establishes the status of milk mother is 5 different feeding times until satiety', (mean $=3.40$ ) or $88.0 \%$ agreement. This is in line with Muslim scholars' views (al-Syafi i, 2001; al-Mawardi, 1996; al-Syirazi, 1983; Ibn Qudamah, 1983; al-Rafi i, 2007 and al-Jassas, 2010). Research respondents also understood well concerning the modes of feeding breast milk to establish milk kinship in item 'Islam permits feeding an infant with expressed milk of milk mother' (mean = 3.55). This proved that respondents understood well that, besides breastfeeding, milk can also be fed through other modes such as expressed milk in a bottle, and so on (al-Nawawi, 2005; Mohammad Nidzam \& Mohd Daud, 2018). In addition, the item 'A mother can feed her milk to someone else's infant subject to her husbands's permission' scored $98 \%$ agreement among respondents (mean $=3.52$ ) and takes fifth highest place in this research. This showed respondents understood that a husband's permission is essential before making a decision to feed breastmilk to someone else's infant. (Ibn Qudamah, 1983; Zaydan, 2000 ). 72.0\% of research respondents do not agree that the milk father can be the guardian in a milk daughter's marriage, while only $28.0 \%$ agree. The basic law regarding this matter is that a milk father cannot be the guardian of his milk daughter in her marriage. This showed a deficit in understanding of milk mothers regarding this matter (Ibn Qudamah, 1983; al-Syatiri, 1997; Zilal, 2014).

This research also found that $87.0 \%$ of respondents agree (mean $=3.30$ ) to the item 'Ablution is nullified if a milk child touches his milk parents'. This shows there is still a deficit in understanding because ablution is not legally cancelled by skin contact between milk child and milk parents. $96.0 \%$ of respondents agree (mean $=3.43$ ) with item 'The aurat limits (or hijab) of a milk child to his milk parents are the same as to his/her biological parents'. This finding is in line with Shariah law and shows that respondents have a good understanding of aurat limits (or hijab). In addition, some respondents lack understanding that a milk child takes the lineage (nasab) of his biological parents as shown by $17.0 \%$ of respondents who disagree with this item. There is also deficit in the respondents' knowledge concerning inheritance whereby $19.0 \%$ of them agree that a milk child may inherit the property of his milk parents.

In Shariah law, ablution is not nullified by touching between a milk child and his milk parents, the aurat limits (or hijab) for the milk child are the same in relation to milk parents as for biological parents and skin contact is permissible between milk child and milk parents. In terms of lineage (nasab), a milk child does not take the lineage of his milk parents. Likewise, a milk father is not the legal guardian of his milk child. Similarly, in the matter of mahram (unmarriageability), a milk child is forbidden to marry his milk parents and milk siblings (al-Mawardi,1996; Zilal, 2014). And as for inheritance, a milk child does not inherit from the milk mother and neither does she from her milk son/daughter. (Ibn Qudamah, 1983; alSyatiri, 1997; Zanariah et al., 2018)

These findings showed certain aspects which are still not well understood by some milk mothers relating to the leral imnlicatinne of milk kinchin These findings are in line with research findings by Syamilah et Loading [MathJax]/jax/output/CommonHTML/jax.js

Page $11 / 18$ 
al. (2015) and Zilal (2015) that there is an issue of some milk mothers still not fully understanding the legal implications of milk kinship. These findings strengthen the view that milk mothers need to improve or enhance their knowledge and understanding on the legal implications of milk kinship.

Besides examining the understanding of milk mothers on the law relating to feeding someone else's infant, this research also studies the factors which encourage mothers to feed their milk to someone else's child. $92.0 \%$ of respondents give the reasons that they do so to help mothers who do not have sufficient milk (mean $=3.36$ ) while $73.0 \%$ do so out of sympathy for infants whose mothers face health problems which prevent them from breastfeeding their infants (mean $=3.01)$. This practice is a good deed as the intention is to help others in need. It is consistent with Islamic teachings as in al-Quran, it is stated " Help you one another in righteousness and piety," (al-Quran, al-Maidah 5:2) and "So race to (all that is) good" (al-Quran, al-Baqarah 2:148). The majority of research respondents, namely $84 \%$, feed someone else's infant because they have surplus milk (mean $=3.18$ ). This is also a good practice in not letting surplus milk go to waste and sharing sustenance of abundant or excessive milk bestowed by feeding the surplus to someone else's child.

Generally, wet nursing is in line with Islamic teachings on the basis of mutual help. This awareness among Muslim women has encouraged them to help each other and at the same time, encouraged mothers to provide breast milk instead of formula milk, which is very nourishing for the physical and mental health of babies and very young children (Mathur \& Dhingra, 2013; Norita et al., 2019). Besides that, this study found that the item "I feed someone else's infant as a source of income" (mean =1.41) has received the least agreement from respondents. This finding shows that research respondents are more inclined to do good to fellow Muslims by helping other mothers in feeding their infants with breast milk. Only $1 \%$ of respondents practise it as a source of income.

\section{Strength And Limitation Of The Study}

Some strengths in this study includes providing novel information regarding wet nursing trends, influences, and practices among a group of Muslim mothers living in Selangor. This study also utilized primary data that should also be considered as the strength of this study. However, there can be recall bias among the respondents since the information was collected retrospectively, one to two years after the wet-nursing practice completed. Due to that, we cannot rule out recall bias in the responses given in the interviews. In this sense, it is possible that the reported breastfeeding rates overestimated the actual rates.

\section{Conclusion}

This study found that the majority of respondents understand the laws relating to feeding breast milk to someone else's infant, especially laws involving marriage, conditions for and modes of feeding breast milk. However, respondents still do not fully understand the laws relating to mahram (unmarriageability), nacah (linoano) nuardianchin and inhoritance involving a milk son/daughter. Research findings show Loading [MathJax]/jax/output/CommonHTML/jax.js

Page $12 / 18$ 
there are quite a variety of factors for women to become a milk mother includes having surplus breast milk, helping mothers who are not able to breastfeed due to underlying illnesses and as a source of income. This research is hoped to create awareness in people who are linked by milk kinship as well as the Muslim society on the importance of understanding the Shariah laws involving feeding breast milk to someone else's infant in order to ensure honorable lineage and also the well-being of the Muslim society.

\section{Abbreviations}

CITC: Corrected Item Total Correlation; SPSS: Statistical Package for Social Sciences; SPM: Sijil Pelajaran Malaysia; PhD: Doctor of Philosophy.

\section{Declarations}

\section{Acknowledgment}

We record the highest appreciation to the Majlis Agama Islam Selangor (MAIS) as a generous contributor to funding the grant (600-IRMI/PBT 5/3(008/2019) for the research entitled Kajian Amalan Radhaah dalam Kalangan Masyarakat Islam di Negeri Selangor (Study of Radha'ah Practice in the Muslim Society of Selangor). Acknowledgement is also given to Universiti Teknologi MARA (UiTM), Faculty of Islamic Studies, Universiti Kebangsaan Malaysia (UKM), Kolej Universiti Islam Antarabangsa Selangor (KUIS), Kementerian Kesihatan Malaysia (KKM) for their support and to expert staff for their contributions in conducting this research. We would like to thank Universiti Teknologi MARA, Universiti Kebangsaan Malaysia, Kolej Universiti Islam Antarabangsa Selangor for constant support and encouragement of expert contributions to conduct this research. We also gratefully acknowledge the cooperation of all the study respondents and staff involved in this project.

\section{Ethics approval and consent to participate}

The study was conducted after getting ethical clearance from Medical Research and Ethics Committee, Ministry of Health Malaysia with code NMRR-20-2503-57029 (IIR). Written informed consent was secured from study respondents after explaining the objective and purpose of the study to each study respondents. The respondents were also assured about the confidentiality of the data.

\section{Consent for publication}

This is not applicable.

\section{Availability of data and materials}

The datasets generated and/or analysed during the current study are not publicly available due to the sensitive nature of the information of the respondents provided but are available from the corresponding author on reasonable request. This is to protect and maintain respondents' anonymity and confidentiality. 


\section{Competing interests}

The authors declare no potential conflicts of interest with respect to the research, authorship, and/or publication of this article.

\section{Funding}

The authors disclosed receipt of the following financial support for the research, authorship, and/or publication of this article through a grant from Selangor Islamic Religious Council, Malaysia [(600IRMI/PBT 5/3 (008/2019)]. Selangor Islamic Religious Council had no role in study design, data collection and analysis, or preparation of the manuscript.

\section{Authors' contributions}

SHH designed the study, developed the search strategy, and drafted the manuscript. NCAR, LAM, RS and ZK refined the search strategy and searched and collected the articles. NB, NMH, MZI and NAA conducted the quality assessment and critically reviewed the manuscript. Lastly, all authors have read and approved the final version of the manuscript.

\section{Acknowledgements}

We would like to thank the Director General of Health Malaysia for permission to publish this study. We would like to thank Universiti Teknologi MARA, Faculty of Islamic Studies, Universiti Kebangsaan Malaysia, Kolej Universiti Islam Antarabangsa Selangor for constant support and encouragement of expert contributions to conduct this research. We also gratefully acknowledge the cooperation of all the study respondents and staff involved in this project.

\section{References}

1. Ahluwalia, I. B., Morrow, B. \& Hsia, J. (2005). Why Do Women Stop Breastfeeding? Findings from the Pregnancy Risk Assessment and Monitoring System. Pediatrics 116(6), 1408-1412.

2. al-Asbahi, Imam Malik bin Anis. (1991). Al-Mudawwanah al-Kubra. Beirut: Dar al-Fikr.

3. al-Baidawi, Nasir al-Din Abi al-Khair 'Abd Allah bin 'Umar bin Muhammad al-Syirazi al-Syafi'i. (t.th.) Anwar al-Tanzil wa Asrar al-Ta'wil @ Tafsir al-Baidhawi. Beyrut : Dar Ihya' al-Turath al-'Arabi. [Tafsir Surah 31:14] https://library.islamweb.net/newlibrary/display_book.php? flag=1\&bk_no=205\&surano=31\&ayano=14

4. al-Dusuqi, Shams al-Din al-Shaikh Muhammad 'Arafah. (t.th.). Hashiyah al-Dusuqi 'Ala al-Sharh alKabir. Kaherah: 'Isa al-Halabi.

5. al-Jassas, Abi Bakr Ahmad bin 'Ali al-Razi. (2010). Syarhu Mukhtasari al-Tahawiy (fi al-Fiqhi alHanafiy). Tahqiq Muhammad 'Ubaid Allah Khan (Dr.). Cet. 1. Jil. 5. Beirut: Syarkah Dar al-Basya'ir alIslamiyyah \& Dar al-Siraj. 
6. al-Kasani, 'Ala'uddin Abi Bakr bin Mas'ud. (2000). Bada'i al-Sana'i fi Tartib al-Shara'i'. Tahqiq Muhammad 'Adnan bin Yasin Darwish. Jil. 3. Beirut: Mu'assasah al-Tarikh al-'Arabi.

7. al-Mawardi, Abu al-Hasan 'Ali ibn Muhammad ibn Habib. (1996). Kitab al-Rada'. Beirut: Dar Ibn Hazm.

8. al-Nawawi, Abi Zakariyya Muhyi al-Din Ibnu Syarrafu. (2005). Minhaju al-Talibin wa 'Umdatu alMuftin. Cet. 1. Beirut: Dar al-Minhaj.

9. Al-Qurtubi, Muhammad bin Ahmad. (2004). al-Jami' li Ahkam al-Qur'an. Beirut: Dar al-Kutub alIlmiyyah.

10. al-Rafi' i, Abi al-Qasim 'Abd al-Karim bin Muhammad bin 'Abd al-Karim al-Qazwini al-Syafi'i. (2007). Syarh Musnad al-Syafi'i. Tahqiq Abu Bakr Wa'il Muhammad Bakr Zahran. Cet. 1. Jil. 4. Qatar: Wizarah al-Awqaf wa al-Syu'un al-Islamiyah Idarah al-Syu'un al-Islamiyyah. http://shamela.ws/browse.php/book-123510\#page-1558

11. Al-Sarkhasi, Abi Bakr Mohammad Ibn Mohammad. t. th. al-Mabsut. Beirut: Dar al-Kutub al-'Ilmiyyah. 12. al-Syafi'i, Abu 'Abd Allah Muhammad bin Idris. (t.th.) al-Umm. Al-Urdun: Bayt al-Afkar al-Dawliyyah. 13. al-Syafi'i, Abu 'Abd Allah Muhammad bin Idris. (2001). al-Umm. Tahqiq Rif'at Fauzi 'Abd al-Mutallib. Mansurah: Dar al-Wafa'.

14. al-Syatiri, Muhammad bin Ahmad. (1997). Syarh al-Yaqut al-Nafis. Beirut: Dar-al-Hawi.

15. al-Syirazi, Taqi al-Din 'Ali ibn 'Abd al-Kafi al-Subki. (1983). Al-Majmu' Sharh al-Muhazzab. Jeddah: Maktabat al-Irshad.

16. Anna Coutsoudis. (2001). Breast-feeding and HIV transmission. Nutrition Research Reviews 14. 191206. South Africa: Department of Paediatrics and Child Health, University of Natal.

17. Ayu Aima Yusuf. (2002). Penyusuan Susu Ibu Menurut Perspektif Islam. Kuala Lumpur: Utusan Publication.

18. Azizah Mohamad. (2011). Potection of rights of adoptive children in relation to duties of adoptive parents under the law in Malaysia. J Adopt Quarterly: 14(4): 229-245. https//doi.org/10.1080/109267552011628261.

19. Baeza, B., Henriquez, F., Prieto, R. (2016) Parenteral postnatal resting: experience in breast feeding of workers mothers using public health system in Region of Araucania of Chile. Revista Chilena De Nutricion. 43(2), 131-137. DOI: 10.4067/S0717-75182016000200004.

20. Berlanga-Macias, C., Alvarez-Bueno, C., Martinez-Hortelano, JA., Garrido-Miguel, M., PozueloCarrascosa, DP., Martinez-Vizcaino, V. (2020). Relationship between exclusive breastfeeding and cardiorespiratory fitness in children and adolescents: A meta-analysis. Scandinavian Journal of Medicine \& Science in Sports. 30(5), 828-836. DOI: 10.1111/sms.13622

21. Del Ciampo, LA., Del Ciampo, IRL. (2018) Breastfeeding and the Benefits of Lactation for Women's Health. Revista Brasileira De Ginecologia E Obstetricia. 40(6), 354-359. DOI: 10.1055/s-00381657766 
22. Dennis, C. L. (2002). Breastfeeding Initiation and Duration: A 1990-2000 Literature Review. Journal of Obstetric, Gynecologic, \& Neonatal Nursing 31(1): 12-32.

23. Flores-Antón, B., García-Lara, N.R., and Pallás-Alonso, C.R. (2017). An adoptive mother who became a human milk donor. Journal of Human Lactation, Vol. 33 No.2, pp. 419-421. https://doi.org/10.1177/ 0890334416682007.

24. Gertosio, C., Meazza, C., Pagani, S., Bozzola, M. (2016). Breastfeeding and its gamut of benefits. Minerva Pediatrica. 68(3), 201-212

25. Gribble, KD. (2006). Mental health, attachment and breastfeeding: implications for adopted children and their mothers. International Breastfeeding Journal. 1(5). DOI: 10.1186/1746-4358-1-5

26. Hagos, D., Tadesse, AW. (2020). Prevalence and factors associated with exclusive breastfeeding among rural mothers of infants less than six months of age in Southern Nations, Nationalities, Peoples (SNNP) and Tigray regions, Ethiopia: a cross-sectional study. International Breastfeeding Journal. 15(1) Article Number: 25. DOI: 10.1186/s13006-020-00267-y.

27. Hapsah Mohd Dusa, Omar Mihat, Mariam Abd. Manaf. (2002). Kajian Pengetahuan, Sikap dan Amalan Berkenaan Penyusuan Susu Ibu Secara Eksklusif di Kalangan Ibu-lbu Hamil yang Mendapatkan Pemeriksaan Antenatal di Klinik Kesihatan Seremban. Jurnal Kesihatan Masyarakat, 8, 67-72.

28. Harris, D.L., Weston, P.J., Harding, J.E. (2019) Does a Good Quality Breastfeed Improve the Blood Glucose Concentration in Hypoglycaemic Babies? Neonatology. 115(3), 234-238.

29. Ibn Rusyd, Muhammad bin Ahmad bin Muhammad bin Ahmad bin Rusyd al-Qurtubi (t.th), Bidayah al-Mujtahid wa Nihayah al-Muqtasid. T.tpt. : Dar al-Fikr.

30. Ibn Qudamah, Abu Muhammad Abdullah bin Ahmad bin Muhammad. (1983). Al-Mughni. Palestin: Dar 'Alam al-Kutub.

31. Lommen, A., Brown, B. (2015). Experiential perceptions of relactation: A phenomenological study. Journal of Human Lactation, 31(3), 498-503.

32. Mathur, N., Dhingra, D. (2013). Breastfeeding. The Indian Journal of Pediatrics. doi:10.1007/s12098013-1153-1

33. Mohammad Nidzam Abdul Kadir \& Mohd Daud Awang. (2018). Penyusuan Kanak-Kanak Melebihi Usia Dua Tahun: Status Anak Angkat Menjadi Anak Susuan. Jurnal al-Anwar, Persatuan Bekas Mahasiswa Islam Timur (PBMITT), 5 (1), 65-78.

34. Norita Kamaruddin, Nora'inan Bahari \& Zanariah Dimon. (2019). Keistimewaan dan Faedah Amalan Penyusuan Susu Ibu. 5th International Seminar on Islamiyyat Studies (IRSYAD 2019 5th \& 6th November 2019, Tenera Hotel, Bangi, Selangor, Malaysia. Organized by Faculty of Islamic Civilisation Studies. International Islamic University College, Selangor, Malaysia.

35. Normadiah Daud, Siti Fatimah Salleh. (2009). Peranan susu ibu dalam pembangunan modal insan: satu sorotan kepada wanita bekerjaya. Jurnal al-Sirat. KIPSAS 8(10). 180 - 197. Kuala Lumpur : Percetakan Tabah. 
36. Normadiah Daud, Zuliza Mohd Kusrin, Salasiah Hanin Hamjah \& Anwar Fakhri Omar. (2012). Penyusuan dan Bank Susu Menurut Islam. Islamiyyat. 34: 107-118.

37. Normadiah Daud, Zuliza Kusrin. (2014). Penyusuan susu ibu: prinsip, hak dan kewajipannya menurut perspektif Islam. E-Jurnal Pengajian Islam. KUIS. 7(1), 155-173.

38. Normadiah Daud, Nadhirah Nordin, Mariam Nabilah Mohd Noor. (2015). Kefahaman ahli akademik IPTA Kuala Terengganu terhadap konsep susuan susu ibu menurut perspektif Islam. E-Jurnal Islam dan Masyarakat Kontemporari. (10). 2 - 18.

39. Radzniwan AR, Azimah NM, Zuhra H, Khairani O. (2009). Breastfeeding practice and knowledge among mothers attending an urban Malaysian maternal and child health clinic. Med \& Health. 4(1) 17. Bangi: Universiti Kebangsaan Malaysia.

40. Rehman, R., Malik, FR., Sabiha, ZU., Rehman, Z. (2017). Awareness of Mothers Regarding Duration and Benefits of Breastfeeding. Gomal Journal of Medical Sciences. 15(2), 78-82.

41. Sandra Fikawati, Ahmad Syafiq. (2010). Kajian Implementasi dan Kebijakan Air Susu Ibu Eksklusif dan Inisiasi Menyusu Dini di Indonesia. Makara, Kesehatan, 14(1), 17-24.

42. Sharbini, al-Khatib. (1978). Mughni al-Muhtaj ila Mar if atal-Maani Alfaz Sharh al-Minhaj. Syria: Dar al-Hadith.

43. Shinde E. (2015). Self-instruction module is effective in improving knowledge of mothers regarding expression and storage of breast milk. Innovational Journal of Nursing and Healthcare (IJNH). 1(3), 193-202.

44. Spiro, A. (2017). The public health benefits of breastfeeding. Perspectives In Public Health. 137(6), 307-308. DOI: 10.1177/1757913917730253.

45. Syamilah Musa, Azimah Mohd Masri, Mohd Norzi Nasir. (2015). Penyusuan Susu Ibu Menurut Perspektif Islam. World Academic and Research Congress 2015 (World-AR 2015) Ar-Rahim Hall, YARSI University, Jakarta, Indonesia, 9th - 10th December 2015.

46. Syh. Noorul Madihah Syed Husin, Normadiah Daud, Tg Fatimah Muliana Tg Muda \& Ramlah Mat Ali (2018). Cabaran Wanita Kerjaya dalam Memenuhi Anjuran Penyusuan Susu Ibu dalam Al-Quran. Prosiding Seminar Antarabangsa al-Quran dalam Masyarakat Kontemporari 2018 International Seminar on al-Quran in Contemporary Society 2018. Fakulti Pengajian Kontemporari Islam (FKI), Universiti Sultan Zainal Abidin (UniSZA).

47. Siti Mariam A. (2013). Support for breastfeeding mothers. Sinar Harian online. Retrieved Jun 20, 2015 from http://www.sinarharian.com.my/rencana/suami-boleh-bantu-jayakan-penyusuan-susuibu-1.192465)

48. Tanriverdi, S., Koroglu, O., Uygur, O., Yalaz, M., Kultursay, N. (2019). Evaluation of macronutrient content of fresh and frozen human milk over 6 months. Journal of Maternal-Fetal \& Neonatal Medicine. DOI: 10.1080/14767058.2019.1651269

49. Tengku Alina Tengku Ismail, Zaharah Sulaiman, Rohana Jalil, Wan Manan Wan Muda, Nik Normanieza Nik Man. (2012). Breast milk, expression among formally employed women in urban 
and rural Malaysia: A qualitative study. International Breastfeeding Journal. 7. 11 - 15. London: BioMed Central.

50. Ward, TL., Hosid, S., Ioshikhes, I. \& Altosaar, I. (2013) Human milk metagenome: a functional capacity analysis. BMC Microbiology Journal. 13. 116 - 120. London: BioMed Central.

51. Zanariah Dimon, Nora'inan Bahari, Norita Kamaruddin \& Nurhayati Abd. Ghani. (2018) HukumHukum Penyusuan Terhadap Anak Susuan: Kajian Kesedaran Masyarakat Islam di Selangor (Ruling Towards Breastfeeding in Islam: Study on Awareness of Muslim Community in Selangor). Journal of Muwafaqat, 1(2), 71-83.

52. Zaydan, Abdul Karim. (2000). al-Mufassal fi Ahkam al-Mar'ah wa Bait al-Muslim fi Syariati alIslamiyyah. Beirut: Dar al-Fikr.

53. Zilal Saari dan Farawahida Mohd Yusof. (2014). Penyusuan Anak Angkat: Satu Analisis. Kertas Kerja Persidangan Antarabangsa Keluarga dari Perspektif Global 2014.

54. Zilal Saari, Farahwahida Mohd Yusof. (2015). Motivating factors to breastfeed an adopted child in a muslim community in Malaysia. Jurnal Teknologi. 74(1): 211-220.

55. Zilal Saari. (2015). Model Garis Panduan Penyusuan Anak Angkat Menurut perspektif Fiqh dan Sains. Skudai: Universiti Teknologi Malaysia. 